\section{SANDIA REPORT}

SAND95-2279 • UC-515

Unlimited Release

Printed November 1995
RECEIVED

NOV 221995

OSTI

\title{
Active Fiber Optic Technologies Used As Tamper-Indicating Devices
}

Patrick R. V. Horton, Ivan G. Waddoups

Prepared by

Sandia National Laboratories

Albuquerque, New Mexico 87185 and Livermore, California 94550

for the United States Department of Energy

under Contract DE-AC04-94AL85000

Approved for public release; distribution is unlimited.
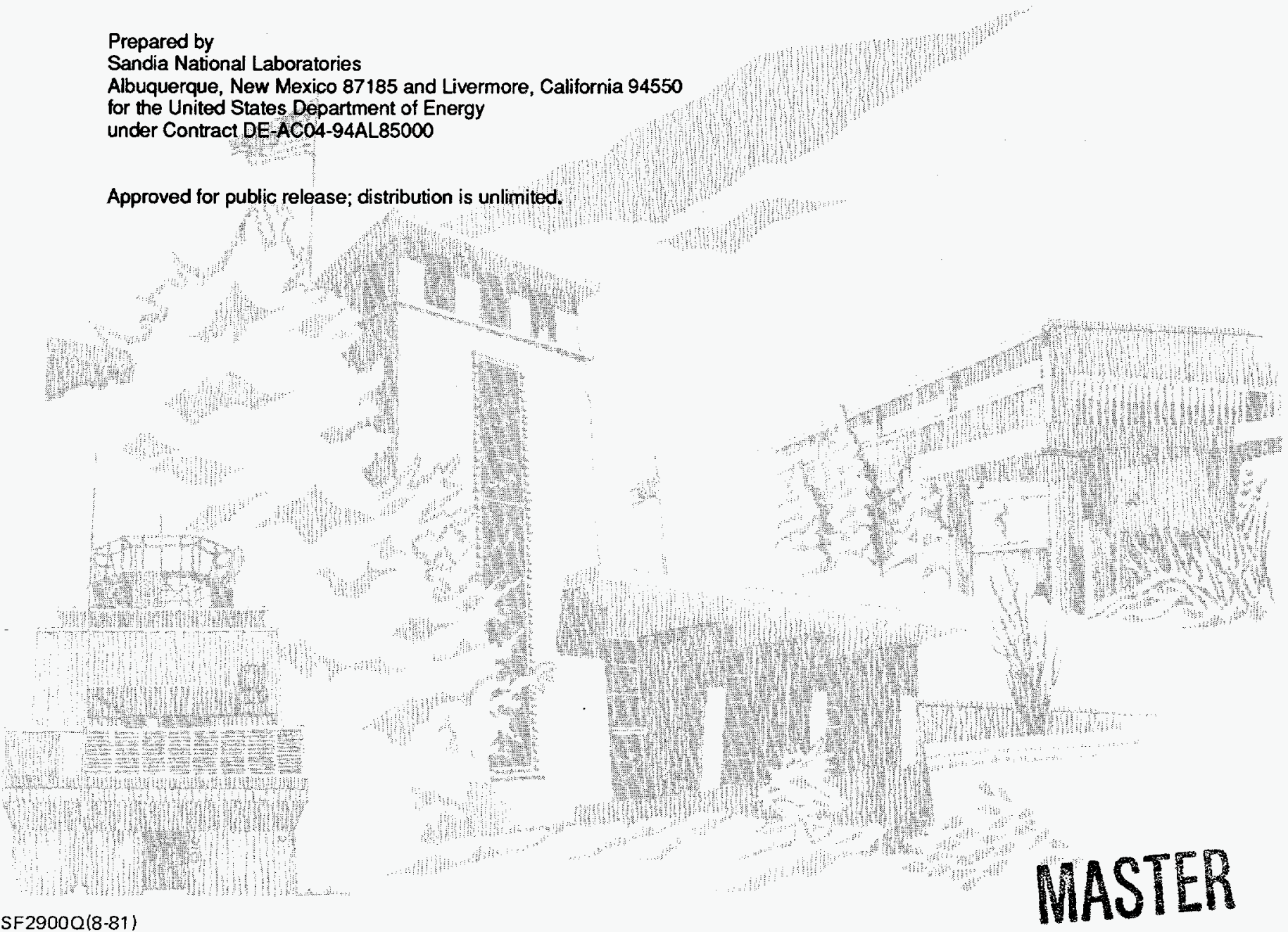
Issued by Sandia National Laboratories, operated for the United States Department of Energy by Sandia Corporation.

NOTICE: This report was prepared as an account of work sponsored by an agency of the United States Government. Neither the United States Government nor any agency thereof, nor any of their employees, nor any of their contractors, subcontractors, or their employees, makes any warranty, express or implied, or assumes any legal liability or responsibility for the accuracy, completeness, or usefulness of any information, apparatus, product, or process disclosed, or represents that its use would not infringe privately owned rights. Reference herein to any specific commercial product, process, or service by trade name, trademark, manufacturer, or otherwise, does not necessarily constitute or imply its endorsement, recommendation, or favoring by the United States Government, any agency thereof or any of their contractors or subcontractors. The views and opinions expressed herein do not necessarily state or reflect those of the United States Government, any agency thereof or any of their contractors.

Printed in the United States of America. This report has been reproduced directly from the best available copy.

Available to DOE and DOE contractors from

Office of Scientific and Technical Information

PO Box 62

Oak Ridge, TN 37831

Prices available from (615) 576-8401, FTS 626-8401

Available to the public from

National Technical Information Service

US Department of Commerce

5285 Port Royal Rd

Springfield, VA 22161

NTIS price codes

Printed copy: A03

Microfiche copy: A01 


\section{DISCLAIMER}

Portions of this document may be illegible in electronic image products. Images are produced from the best available original document. 


\title{
SAND95-2279 • UC-515 \\ Unlimited Release \\ Printed November 1995
}

\section{ACTIVE FIBER OPTIC TECHNOLOGIES USED AS TAMPER-INDICATING DEVICES}

\author{
Patrick R.V. Horton \\ Safeguards Seals Evaluation Program Coordinator \\ Ivan G. Waddoups \\ Insider Technology Department, Manager \\ Sandia National Laboratories/NM \\ Albuquerque, NM 87185-0759
}

\begin{abstract}
The Safeguards Seals Evaluation Program is considering new fiber optic active seal technologies (AST) that can be used at DOE facilities. The goal is to investigate tamper-indicating devices (TID) that can be used to monitor secured containers within vaults while personnel remain outside the vault area. Such a system would allow minimal required access into vaults to verify container TID integrity while ensuring container content accountability. The TID concepts that hold the most promise and keep cost factors down are fiber optic and radio frequency technologies. Four existing manufactured technologies were considered and tested.
\end{abstract}




\section{ACKNOWLEDGMENTS}

- Dennis Nelson, Reactor Applicatrion Dept., Org. 6521 at SNL-NM for radiation testing at the Gamma Irradiation Facility.

- Phil Garcia, Robert Martinez, and David Straub, Surety Technology Dept. II, Org. 5932 at SNL-NM for blackhatting support.

- Theresa Bourne, DOE Security Programs Dept., Org 5804 at SNL-NM for technical writing support while in review.

- Rodney Conrad, VSS Fiber Optic Sensors (Denver, CO) for providing exceptional product support on his active seals technology before and after the sale.

- Bot Heimbecker, ITI Interactive Technologies, Inc. (North St. Paul, MN) for providing product support on his active seals technology.

- Sandra Reynolds and Duane Thompson, Fiber SenSys, Inc. (Beaverton, OR) ) for providing product support on their active seals technology.

- Steve Koonce, Inovonics (Boulder, CO), ) for providing product support on his active seals technology. 


\section{CONTENTS}

ACKNOWLEDGMENTS .iv

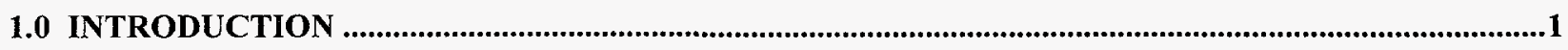

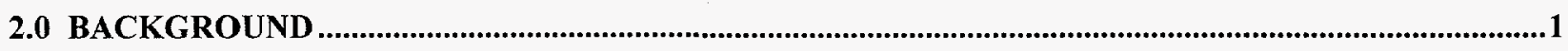

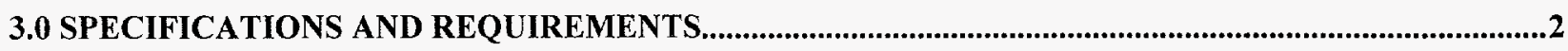

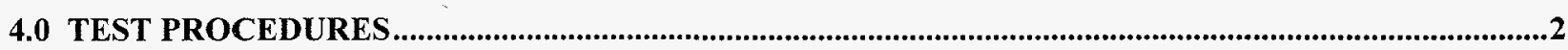

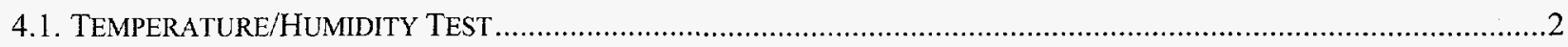

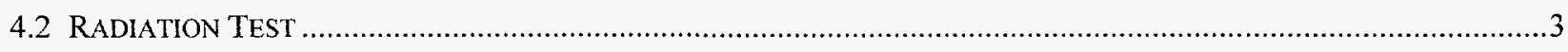

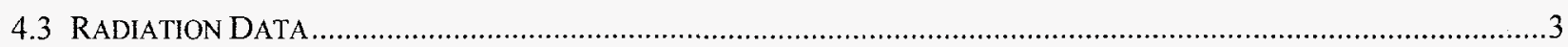

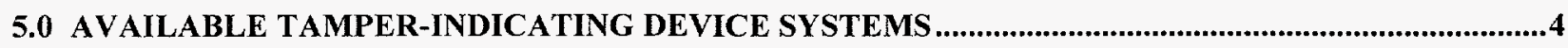

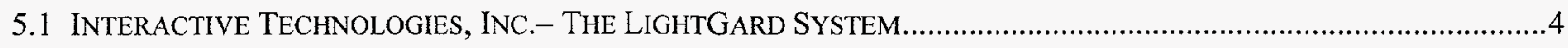

5.2 FIBER SENSYS, INC. - FIBER OPTIC INTRUSION DETECTION SYSTEM ……................................................

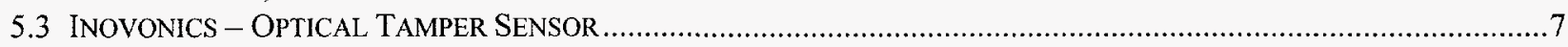

5.4 VALVE SECURITY SYSTEMS, INC. - FIBER OPTIC SENSOR SYSTEM …….................................................

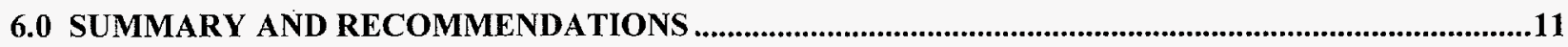

Figures

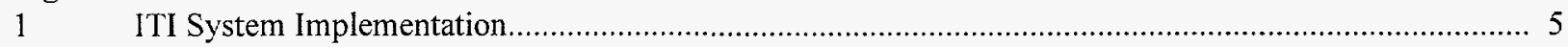

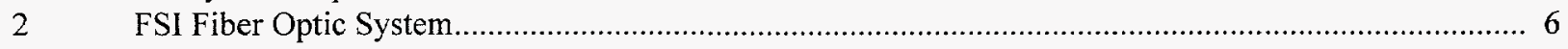

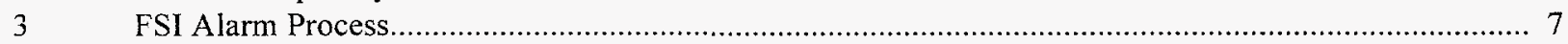

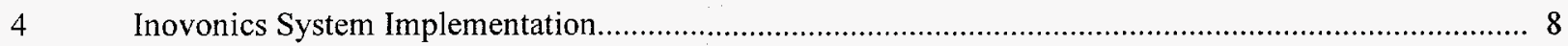

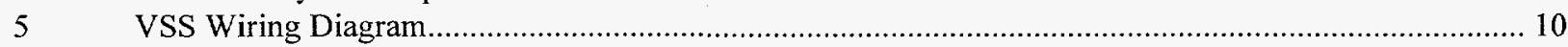

\section{Tables}

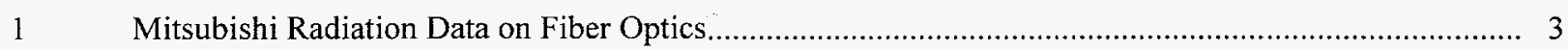

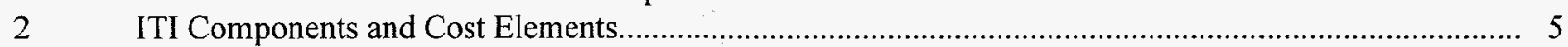

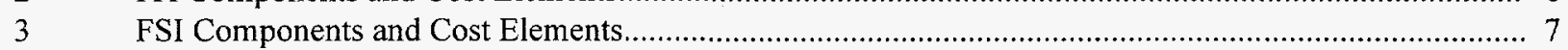

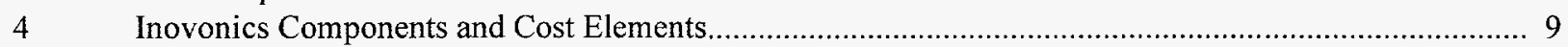

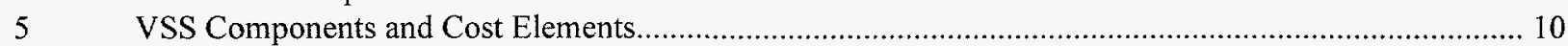

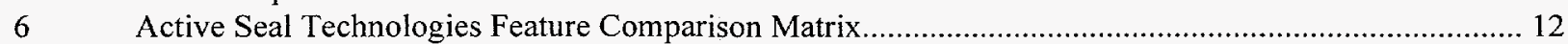

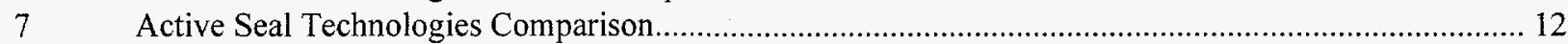


Page Intentionally Left Blank 


\section{ACTIVE FIBER OPTIC TECHNOLOGIES USED AS TAMPER-INDICATING DEVICES}

\subsection{Introduction}

The Sandia National Laboratories (SNL) Safeguards and Seals Evaluation Program is evaluating new fiber optic active seal technologies for use at Department of Energy (DOE) facilities. The goal of the program is to investigate active seal technologies that can monitor secured containers storing special nuclear materials (SNM) within DOE vaults. Specifically investigated were active seal technologies that can be used as tamper-indicating devices to monitor secured containers within vaults while personnel remain outside the vault area. Such a system would allow minimal access into vaults while ensuring container content accountability.

The purpose of this report is to discuss tamper-indicating devices that were evaluated for possible DOE use. While previous seal evaluations (Phase I and II) considered overall facility applications, this discussion focuses specifically on their use in vault storage situations. The report will highlight general background information, specifications and requirements, and test procedures. Also discussed are the systems available from four manufacturers: Interactive Technologies, Inc., Fiber SenSys, Inc., Inovonics, Inc., and Valve Security Systems.

\subsection{Background}

Sealed containers store SNM in DOE facility vaults under the two-person access rule. In this environment, the relatively unsophisticated tamper-indicating devices provide significant protection against tampering of SNM containers and help to decrease the time personnel spend inventorying SNM. Site personnel quickly and easily determine if the containers have been tampered with which results in reduced radiation exposure.

The tamper-indicating devices currently used are one of two types: pressure sensitive seals or loop seals. These seals (a term used interchangeably with tamper-indicating devices) are placed on the containers to ensure that the contents have not been compromised.

The containers that require seals come in various textures, shapes, and sizes. The largest containers (5-, 10-, 30-, and 55-gallon) are typically painted drums with closure-locking collars. Smaller sized cans (1/8-, 1-, 3-, and 5-gallon) are usually plated.

All containers using tamper-indicating devices are located primarily in protected environments (i.e., inside buildings), and are stored in various configurations. For instance, some drums or cans are placed in an open storage environment, while others are stacked on shelves or in cabinets. The storage method is determined by container content, the amount of containers, and the need for accessibility. 


\subsection{Specifications and Requirements}

In order for DOE to rely on tamper-indicating devices to monitor SNM and other critical assets, these seals must meet the following specifications:

- be sold at a reasonable cost

- remain intact, readable, and viable for at least 2 years after application

- indicate seal integrity

- secure a variety of containers or storage cabinets

- indicate any attempt to tamper with the device

- provide relative ease and speed of application

- fit a variety of containers.

Another somewhat arbitrary goal for the active seal technologies is that the system cost $\$ 100$ or less per container monitored. This cost factor, therefore, must be considered when determining the type of tamper-indicating device and the storage method.

\subsection{Test Procedures}

The goal of the SNL testing was to ensure that the seals operated properly in known environmental conditions and that they met the specifications mentioned above. To meet this objective, SNL personnel used the military standard 810D, dated July 19, 1983, to establish the proper conditions for testing seals. These included temperature/humidity and radiation exposure tests.

\subsection{Temperature/Humidity Test}

The following 24-hour temperature/humidity procedure tested the seals at various temperatures and levels of humidity over a 20 -day period. This determination is valuable because the tamperindicating devices are used in situations and conditions where the temperature and humidity vary.

- The test began at $72^{\circ} \mathrm{F}$ and $35 \%$ humidity. This condition stayed constant for 6 hours.

- During the next 6 hours, the chamber temperature was slowly raised to $95^{\circ} \mathbf{F}$ and the humidity level was raised to $\mathbf{9 5 \%}$.

- Once the chamber reached $95^{\circ} \mathrm{F}$ and $95 \%$ humidity, the temperature was maintained for 6 hours and the humidity level was kept constant for 5 hours.

- At the end of 5 hours, personnel started to drop the $95 \%$ humidity to $35 \%$.

- At the end of 6 hours, personnel started to drop the $95^{\circ} \mathrm{F}$ temperature back down to $72^{\circ} \mathrm{F}$. This took 6 hours. (This portion of the test determined humidity tolerance but kept the humidity below the dew point, which would have caused condensation.)

- One 24-hour cycle was completed at this point. The cycle was repeated 20 times.

All tamper-indicating devices passed the temperature/humidity tests. 


\subsection{Radiation Test}

Units from three of the manufacturers - Interactive Technologies, Inc., Fiber SenSys, Inc., and Valve Security Systems - were tested at the SNL Gamma Irradiation Facility using Cobalt 60. To monitor total radiation exposure, thermoluminescence dosimeters were placed on the front and back of the circuit cards of each of the sensor units. The dosimeters were labeled, and total shot times were recorded.

The three units were irradiated at a rate of $1500 \mathrm{R}$ per hour for 2.5 hours (a total of 3,750 R). They were then inspected to determine if the tamper-indicating features responded to a tamper. One such feature is a tamper-indicating light that acts as a "state-of-health" indicator. These lights were visually inspected through an inspection window every 10 minutes.

After receiving 6,808 $\mathrm{R}$ (approximately 5 hours into the test), the Fiber SenSys unit failed. A "hands-on" evaluation was then conducted, and the unit was removed from the chamber. The two remaining units were tested for 2.5 more hours. These received a total of $8,918 \mathrm{R}$ and were determined to have passed the test.

The Inovonics units were received too late for the Cobalt 60 testing but an opportunity opened for a slightly different test. This test also provided an opportunity to utilize lower dose rates. Two units were tested using Cesium 137 at the SNL Radiation Standards Facility at a dose rate of $15 \mathrm{R}$ per hour. These units failed at an average level of $6,833 \mathrm{R}$.

\subsection{Radiation Data}

Though not directly tested at SNL, the effects of radiation on fiber optic cables were researched. Three of the four manufacturers use plastic fiber optic cables that are sold by Mitsubishi Corporation. As part of the effort to determine radiation effects on the total tamper-indicating device systems, we obtained a data sheet from Mitsubishi Corporation that presents radiation data (Table 1). The sheet specifically highlights the attenuation change that occurs in the fiber optic cables after exposure to Cobalt 60 radiation.

Table 1 - Mitsubishi Radiation Data on Fiber Optics

\begin{tabular}{|c|c|c|c|c|}
\hline dosage & attenuation & \multicolumn{3}{|c|}{ attenuation change } \\
\hline RAD & $\begin{array}{l}\text { before } \\
\text { radiation }\end{array}$ & $\begin{array}{l}\text { immediately } \\
\text { after radiation }\end{array}$ & $\begin{array}{l}1 \text { hour } \\
\text { after radiation }\end{array}$ & $\begin{array}{l}1 \text { month } \\
\text { after radiation }\end{array}$ \\
\hline 9,300 & $140 \mathrm{~dB} / \mathrm{km}$ & $408 \mathrm{~dB} / \mathrm{km}$ & $426 \mathrm{~dB} / \mathrm{km}$ & $154 \mathrm{~dB} / \mathrm{km}$ \\
\hline 90,300 & $140 \mathrm{~dB} / \mathrm{km}$ & $474 \mathrm{~dB} / \mathrm{km}$ & $528 \mathrm{~dB} / \mathrm{km}$ & $185 \mathrm{~dB} / \mathrm{km}$ \\
\hline 900,300 & $140 \mathrm{~dB} / \mathrm{km}$ & $2,917 \mathrm{~dB} / \mathrm{km}$ & $2,420 \mathrm{~dB} / \mathrm{km}$ & $153 \mathrm{~dB} / \mathrm{km}$ \\
\hline
\end{tabular}

The Mitsubishi data shows that the fiber light attenuation immediately increases a significant amount when exposed to fairly high radiation levels. After one month, the fiber demonstrates a "self-healing" process that returns the attenuation value near the original. This data and our testing lead us to the conclusion that the low dose rates $(20-200 \mathrm{MR}$ per hour) at DOE facilities 
should result in 1) minimal attenuation increases when the dose is incurred and 2) very little long-term accumulated attenuation.

Data on Corning glass fiber optic cables was not available. However, several U.S. scientists who have tested both types of fiber optics believe that glass fiber optics perform better than plastic units. Another important factor in performance is the quality of glass used. An inferior glass product can perform poorly.

\subsection{Available Tamper-Indicating Device Systems}

The following section discusses four manufacturer's systems presently on the market that might be used to monitor secured containers within vaults. These systems employ various fiber optic and radio frequency technologies and offer unique sensing capabilities. In all four discussions, a 55-gallon drum will be used to discuss possible DOE applications. Although it may be desirable in some applications, we have not included in-line connectors for ease of loop opening. If three connectors are included, the maximum loop length is reduced by $20 \%$. Individual system costs are also discussed.

\subsection{Interactive Technologies, Inc. - The LightGard System}

Interactive Technologies, Inc., (ITI) uses plastic fiber optics and radio frequency technologies in security systems for businesses and universities. These systems contain in-line fiber optic connectors for removing secured property (i.e., for inventory or property transfer). The ITI transceiver is designed to use a maximum of 150 feet of fiber optic cable and can protect up to 16 drums in an open shelf/large container vault (Figure 1).

The system's SX-V central processing unit (CPU) can handle 61 of the LightGard transceivers (zones) and is tied into a central station receiver (CSR). The CSR can handle 336,000 SX-Vs via secured phone line. The electronics of the LightGard pulses a light source through one end of the fiber optic loop. The same pulse should be seen through the other end of the loop which is connected to a light-sensing photo detector. If the pulse is not seen, an RF or hardwire signal is delivered to the SX-V that transmits a signal to the CSR.

The transceiver body enclosure measures $4 " \times 6.5^{\prime \prime} \times 2.5^{\prime \prime}$ and provides three external LED indicators. The green is 'power on,' the red is the fiber-optic loop 'alarm,' and the yellow is the 'tamper switch' that alarms when the enclosure is lifted from a horizontal surface. Another internal switch alarms when the lid is removed.

Table 2 illustrates the ITI system components and their cost. As illustrated, one zone with 16 containers does not meet the $\$ 100$ maximum average cost. However, three zones with 48 containers would cost $\$ 84$ per container. 
ITI's

Central Station
Receiver $\Rightarrow$ CS 4000

ITI's Touch Pad/Display $\Longrightarrow$

TeleComunications Line

ITI's Wire Harness

(1)

ITT's

LiteGard Light

Transceiver

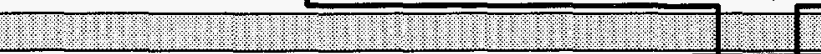

ITI's

Fiber Optic

Connector
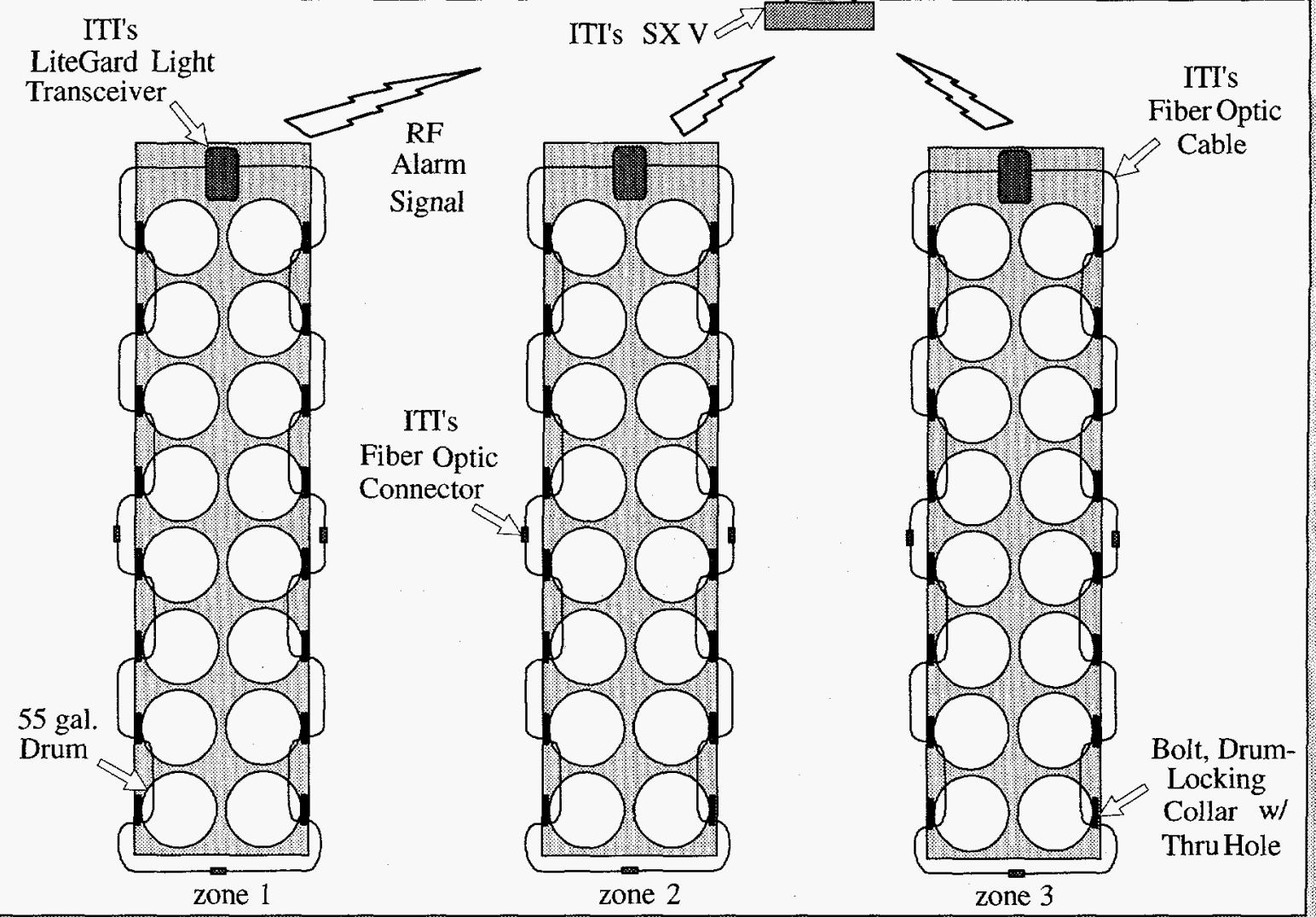

Fiber Optic
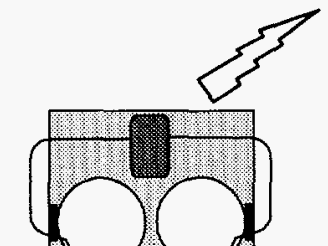

2 
detect motion, vibration, and pressure changes along the entire length of the fiber optic loop.

Figure 2 illustrates the FSI system's assembly that could be used in a vault. The system could secure 100 containers in one zone using 656 feet of fiber optic cable.

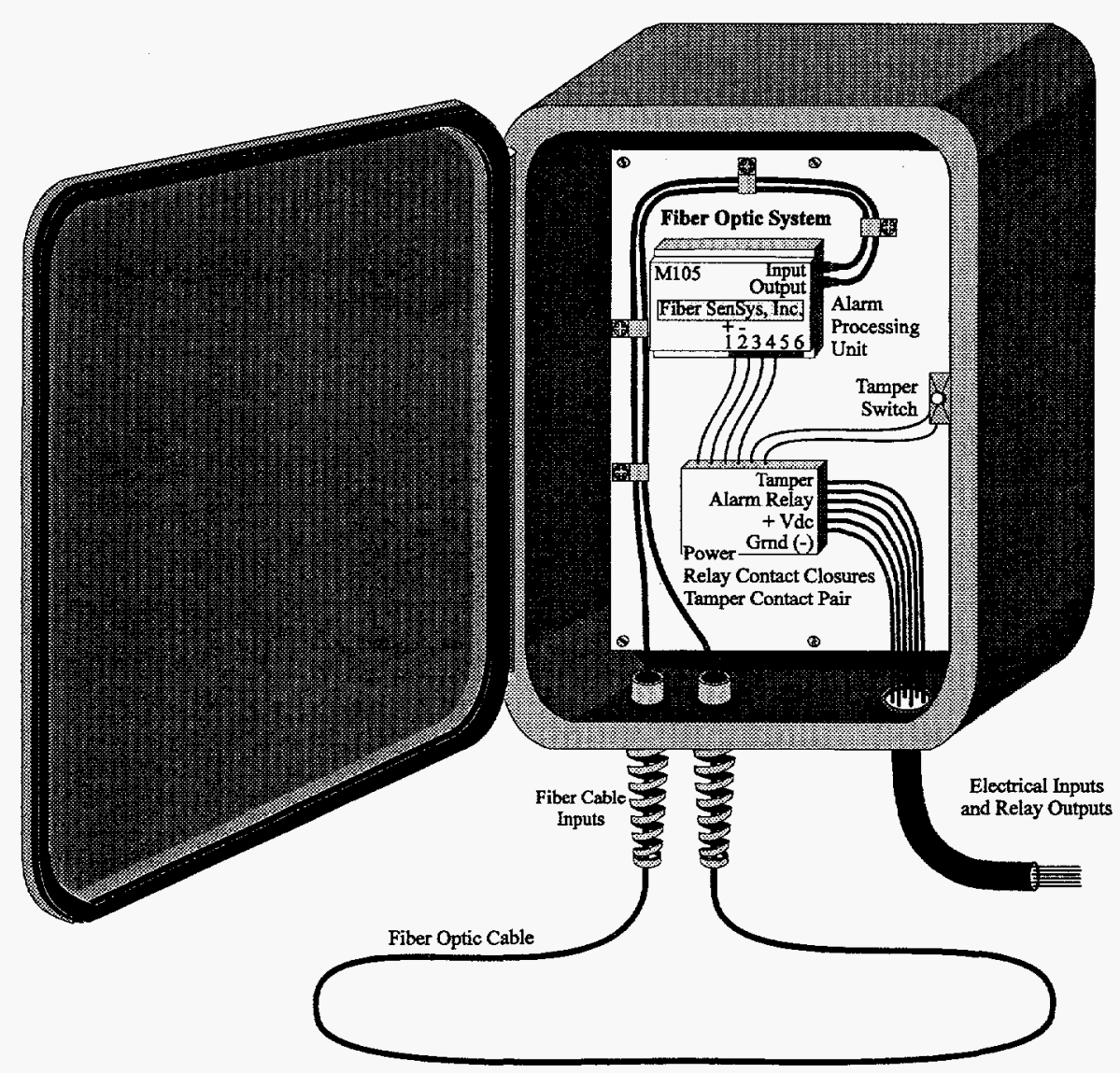

Figure 2 - FSI Fiber Optic System

The FSI system pulses a laser light source through one end of the fiber optic loop. The same pulse should be seen through the other end of the loop that is connected within the same RF unit. If the pulse is not as expected, a radio frequency or hardwire signal is delivered to the transceiver which in turn transmits a signal to a computer link. The alarm processing unit (APU) is radio frequency linked to a transceiver that can handle 100 APUs.

The FSI system requires a hand-held calibrator with a security key. The calibrator is a programming unit with an alphanumeric keypad and a two-line LCD display. The system also contains seven alarm processing parameters that are used to discriminate natural phenomena from an intruder. Figure 3 shows how this alarm process works. 


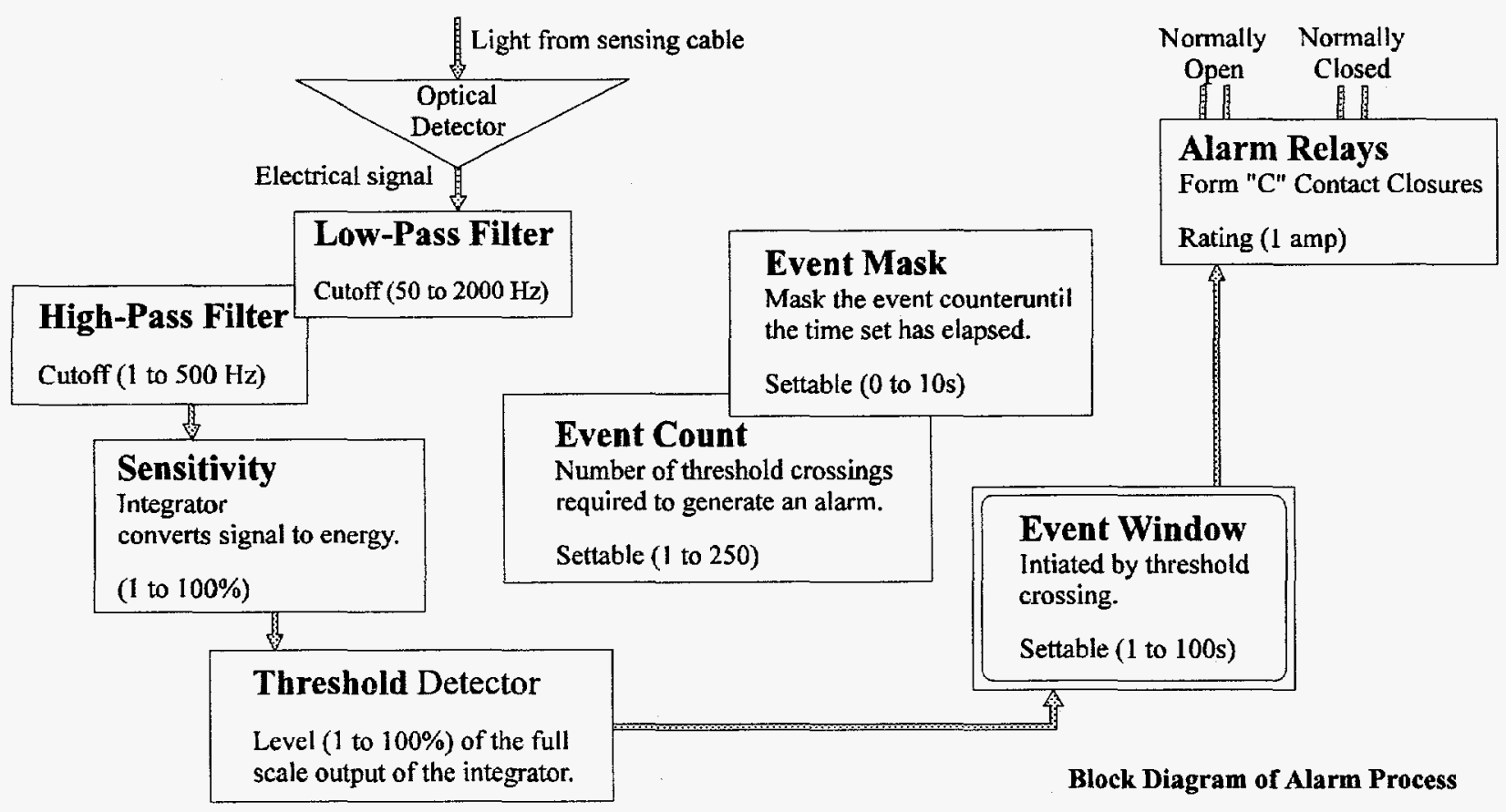

Figure 3 - FSI Alarm Process

Table 3 shows the FSI system components and their cost. As illustrated, one zone with 100 containers does not meet the $\$ 100$ maximum average cost. However, two zones with 200 containers would cost $\$ 93$ per container.

Table 3 - FSI Components and Cost Elements

\begin{tabular}{|c|c|c|c|c|c|c|c|}
\hline & Zones & 1 & 2 & 3 & 20 & 40 & 60 \\
\hline & Total Containers & 100 & 200 & 300 & 2,000 & 4,000 & 6,000 \\
\hline Equip. & Description & \multicolumn{6}{|c|}{ Cost } \\
\hline \multirow{2}{*}{$\begin{array}{c}\mathrm{CPU} \\
\text { Annunicator } \\
\text { Panel }\end{array}$} & PC, Printer, Software & $\$ 4,000$ & $\$ 4,000$ & $\$ 4,000$ & $\$ 4,000$ & $\$ 4,000$ & $\$ 4,000$ \\
\hline & Up to 100 zones & $\$ 3,500$ & $\$ 3,500$ & $\$ 3,500$ & $\$ 3,500$ & $\$ 3,500$ & $\$ 3,500$ \\
\hline M105 & Alarm processing card & $\$ 1,850$ & $\$ 3,700$ & $\$ 5,550$ & $\$ 37,000$ & $\$ 66,600$ & $\$ 99,900$ \\
\hline SC-200 & $\begin{array}{c}\text { Fiber optic cable } 656 \\
\text { ft. lengths }\end{array}$ & $\$ 550$ & $\$ 1,100$ & $\$ 1,650$ & $\$ 5,500$ & $\$ 5,500$ & $\$ 5,500$ \\
\hline Calibrator & $\begin{array}{c}\text { Hand calibrator for } \\
\text { sensors }\end{array}$ & $\$ 1,350$ & $\$ 1,350$ & $\$ 1,350$ & $\$ 1,350$ & $\$ 1,350$ & $\$ 1,350$ \\
\hline \multirow[t]{3}{*}{$\begin{array}{c}\text { Transceiver } \\
\text { RF Set } \\
\end{array}$} & $\begin{array}{c}\mathrm{RF} \text { transceiver pair \& } \\
\text { antennas }\end{array}$ & $\$ 5,000$ & $\$ 5,000$ & $\$ 5,000$ & $\$ 5,000$ & $\$ 5,000$ & $\$ 5,000$ \\
\hline & Total System Cost & $\$ 16,300$ & $\$ 18,650$ & $\$ 21,050$ & $\$ 56,000$ & $\$ 84,000$ & $\$ 140,000$ \\
\hline & Cost per container & $\$ 163$ & $\$ 93$ & $\$ 70$ & $\$ 28$ & $\$ 21$ & $\$ 20$ \\
\hline
\end{tabular}

\subsection{Inovonics - Optical Tamper Sensor}

The C-209 Optical Tamper Sensor (OTS) by Inovonics is a sensor manufactured for a single customer who requires a high-security, tamper-resistant unit. SNL's On-Site Monitoring Technology Department, in conjunction with Inovonics, is implementing a modified OTS unit into 
Technology Department, in conjunction with Inovonics, is implementing a modified OTS unit into their Universal Authenticated Item Monitoring System (AIMS). The OTS is a plastic fiber optic seal sensor that uses up to 100 feet of fiber optics with a random-pulsing light and radio frequency link to an Inovonics C-403 serial receiver. This modified OTS is referred to as the AIMS Fiber Optic Seal (AFOS) sensor. The modifications provide the sensor with an authenticated radio frequency communication link that communicates with an RPU and a computer interface. However, due to the cost of the modified OTS and the RPU, it was decided to evaluate the OTS as received from Inovonics.

Figure 4 illustrates an Inovonics layout in a vault with stacked 55-gallon drums. The Inovonics C-403 serial receiver is hardwire connected to an RS-232 compatible serial port. The global outputs of the C-403 can indicate when any point in the system reports a fault or fails to report as expected. The programmable options of the $\mathrm{C}-403$ are stored in an Electronically Erasable Programmable Memory. These options may be modified through the receiver's serial port that is connected to a serial port on a personal computer or other host device.

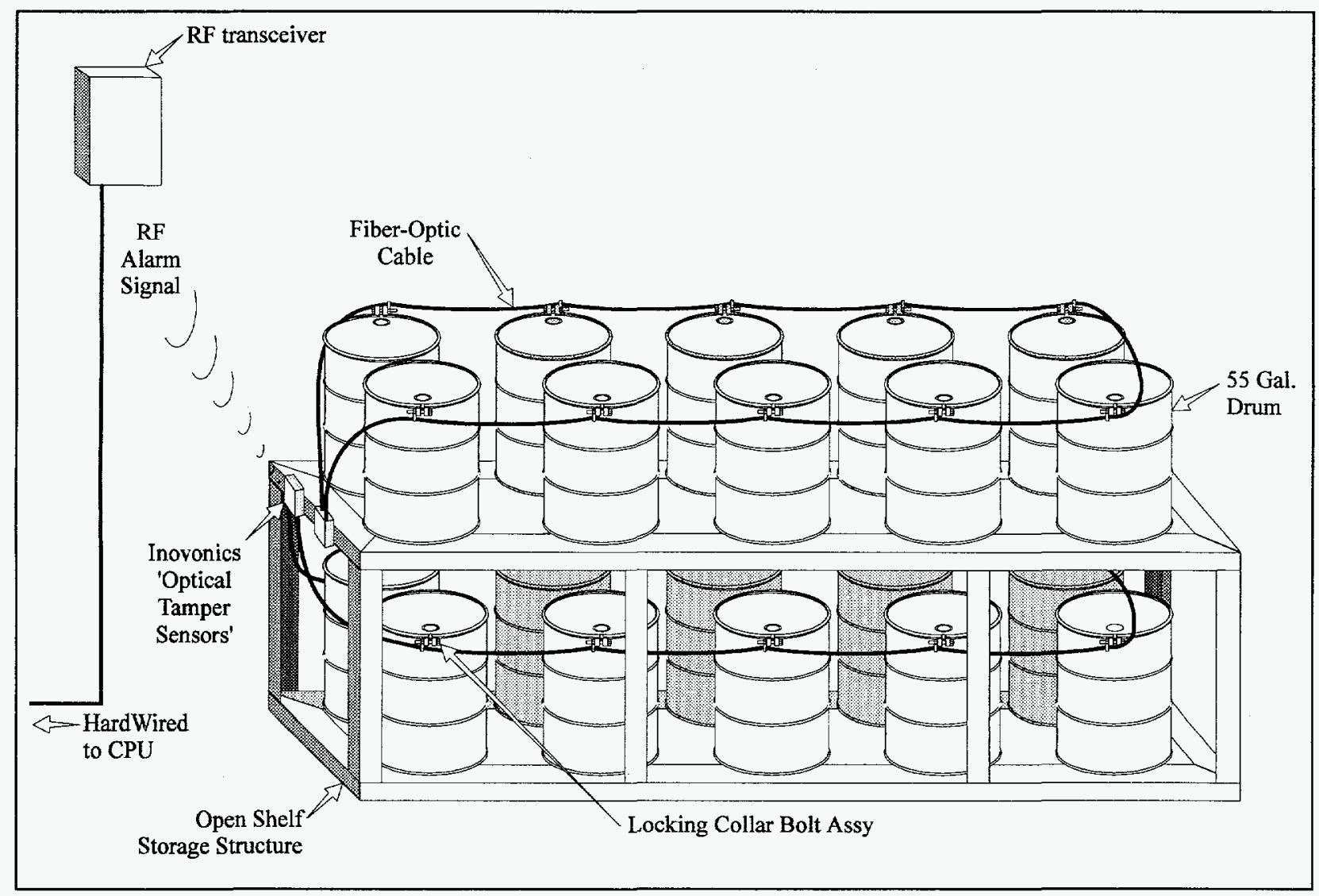

Figure 4 - Inovonics System Implementation

Table 4 illustrates the Inovonics system components and their cost. As applied in a similar fashion for the previous two systems, one zone with ten containers does not 
Table 4 - Inovonics Components and Cost Elements

\begin{tabular}{|c|c|c|c|c|c|c|c|}
\hline & Zones: & 1 & 10 & 20 & 40 & 60 & 80 \\
\hline & otal Containers & 10 & 100 & 200 & 400 & 600 & 800 \\
\hline Equipment & Description & \multicolumn{6}{|c|}{ Cost } \\
\hline C209 & $\begin{array}{l}\text { Optic Tamper Sensor } \\
\text { Setup Charge }\end{array}$ & $\begin{array}{r}\$ 98 \\
\$ 258\end{array}$ & $\begin{array}{l}\$ 980 \\
\$ 258\end{array}$ & $\begin{array}{r}\$ 1,920 \\
\$ 258\end{array}$ & $\begin{array}{r}\$ 3,840 \\
\$ 258\end{array}$ & $\begin{array}{r}\$ 5,760 \\
\$ 258\end{array}$ & $\begin{array}{r}\$ 7,680 \\
\$ 258\end{array}$ \\
\hline Cable & $\begin{array}{l}100 \mathrm{ft} \text {. Fiber-Optic } \\
\text { lengths }\end{array}$ & $\$ 29$ & $\$ 290$ & $\$ 580$ & $\$ 1,160$ & $\$ 1,740$ & $\$ 2,320$ \\
\hline $\mathrm{C} 403$ & $\begin{array}{l}\text { RF Receiver } \\
\text { Processing }\end{array}$ & $\begin{array}{r}\$ 170 \\
\$ 2,000\end{array}$ & $\begin{array}{r}\$ 170 \\
\$ 2,000\end{array}$ & $\begin{array}{r}\$ 170 \\
\$ 2,000\end{array}$ & $\begin{array}{r}\$ 170 \\
\$ 2,000\end{array}$ & $\begin{array}{r}\$ 170 \\
\$ 2,000\end{array}$ & $\begin{array}{r}\$ 170 \\
\$ 2,000\end{array}$ \\
\hline \multirow{2}{*}{\multicolumn{2}{|c|}{$\begin{array}{l}\text { Total System Cost } \\
\text { Cost per Container }\end{array}$}} & $\$ 7,386$ & $\$ 8,511$ & $\$ 9,761$ & $\$ 12,261$ & $\$ 14,761$ & $\$ 17,261$ \\
\hline & & $\$ 739$ & $\$ 85$ & $\$ 49$ & $\$ 31$ & $\$ 25$ & $\$ 22$ \\
\hline
\end{tabular}

\subsection{Valve Security Systems, Inc. - Fiber Optic Sensor System}

Valve Security Systems, Inc., (VSS) uses plastic fiber optics with hardwire power and communication links in their VSS 300B security system. Like the ITI System, the VSS unit contains in-line fiber optic connectors and a user-friendly connect/disconnect concept for removing secured property (for inventory or property transfer).

The Network Control Box (NCB) for the VSS system can be configured to accommodate up to 41 sensors $(2,624$ drums). It takes one single communication wire to carry the signal from the distribution box to the computer. The computer can process up to 10,000 VSS sensors while addressing each one individually.

As with the ITI and FSI systems, the fiber optic sensor electronically pulses a light source through one end of the fiber optic loop. The same pulse should be seen through the other end of the loop that is connected to a light-sensing photo detector. If the pulse is not seen, a hardwire signal is delivered to the NCB distribution box.

The VSS 300B fiber optic sensor provides an RS-485 multi-drop bus system where all the sensors can be connected in a series. Up to 60 sensors can be interconnected from this fourwire bus. The interconnection eliminates the need for separate connections between each sensor and a distribution device (a single connection terminates in the NCB). This connection may be extended up to 2,000 feet. In addition, each sensor can poll itself as often as desired to conduct self performance tests. The sensor also contains a supervised circuit that will detect a cable break as well as an LED light on the exterior body. This light indicates fiber optic continuity and whether the sensor is in monitoring mode.

Approximately 500 feet of fiber optic cable can be used with the system. Each loop can protect up to 80 drums in one zone. Figure 5 shows a wiring diagram of the VSS $300 \mathrm{~B}$ system. 


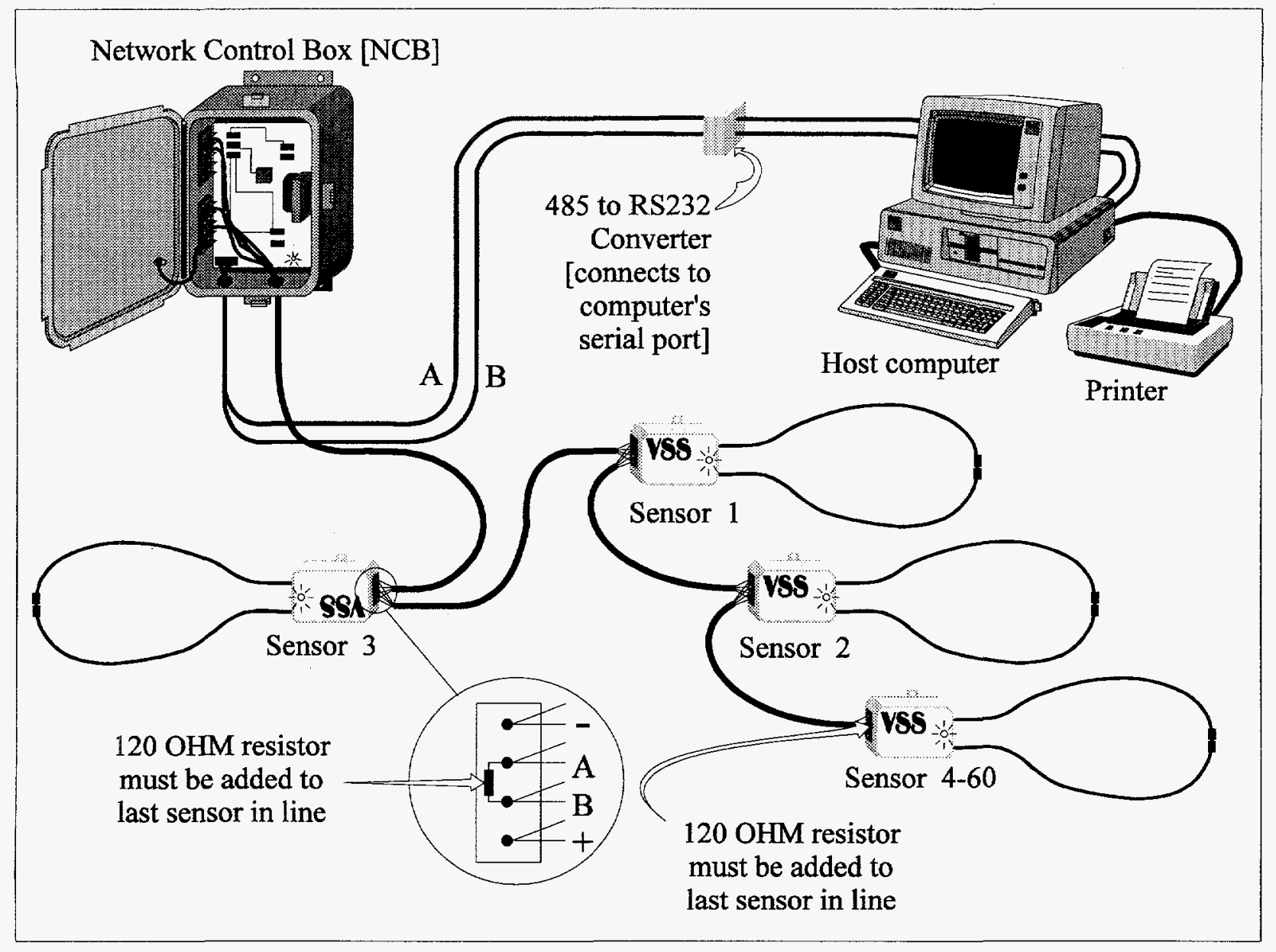

Figure 5 - VSS Wiring Diagram

Table 5 shows the VSS system components and their cost. As illustrated, one zone with 80_containers meets the $\$ 100$ maximum average cost at $\$ 48$ each.

Table 5 - VSS Components and Cost Elements

\begin{tabular}{|c|c|c|c|c|c|c|c|}
\hline & Zones & 1 & 7 & 10 & 20 & 80 & 100 \\
\hline & Total Containers & 80 & 560 & 800 & 1,600 & 6,400 & 8,000 \\
\hline Equipment & Description & \multicolumn{6}{|c|}{ Cost } \\
\hline VSS 300B & $\begin{array}{c}\text { Sensor body } \\
500 \mathrm{ft} \text { fiber optics }\end{array}$ & $\$ 514$ & $\$ 3,598$ & $\$ 5,140$ & $\$ 10,280$ & $\$ 41,120$ & $\$ 51,400$ \\
\hline \multirow{2}{*}{ Model 3500} & Network Control Box & $\$ 859$ & $\$ 859$ & $\$ 859$ & $\$ 859$ & $\$ 1,718$ & $\$ 1,718$ \\
\hline & $\begin{array}{l}\text { Receiver Processing Unit } \\
\text { Software }\end{array}$ & $\begin{array}{r}\$ 2,000 \\
\$ 500\end{array}$ & $\begin{array}{r}\$ 2,000 \\
\$ 500\end{array}$ & $\begin{array}{r}\$ 2,000 \\
\$ 500\end{array}$ & $\begin{array}{r}\$ 2,000 \\
\$ 500\end{array}$ & $\begin{array}{r}\$ 2,000 \\
\$ 500\end{array}$ & $\begin{array}{r}\$ 2,000 \\
\$ 500\end{array}$ \\
\hline & Total System Cost & $\$ 3,873$ & $\$ 6,957$ & $\$ 8,499$ & $\$ 13,639$ & $\$ 45,338$ & $\$ 55,618$ \\
\hline & Cost per Container & $\$ 48$ & $\$ 12$ & $\$ 11$ & $\$ 9$ & $\$ 7$ & $\$ 7$ \\
\hline
\end{tabular}




\subsection{Summary and Recommendations}

Fiber optic products from four manufacturers were evaluated as tamper-indicating devices for DOE use even though the manufacturer's intended use of their product might be for some other purpose. The four products tested were:

- The Fiber SenSys, Inc. - M105 Intrusion Detection System, used mainly for exterior perimeter security.

- Inovonics, Inc. - C-209 Optical Tamper Sensor, used as a personnel tracking device in private industry.

- Interactive Technologies, Inc. - LightGard, used by businesses and universities to secure property (computers, etc.) for inventory and theft protection.

- Valve Security Systems - VSS-300B Fiber Optic Sensor, developed for hospital valve monitoring of exotic gases. The Navy is now testing the system on the USS Kitty Hawk for fuel ballast transfer and for ship refueling. VSS also advertises their sensors for computer anti-theft detection and inventory.

The tamper-indicating devices used are either glass fiber optics or plastic fiber optics with electronics that indicate a tamper through radio frequency and/or hardwire communications. They must meet the following specifications:

- reasonable cost

- resistance to environmental conditions (must remain functional and viable for at least 2 years subsequent to installation)

- ability to secure a variety of containers or storage cabinets

- ability to indicate attempts to tamper with the device

- relative ease and speed of application

- ability to fit a variety of containers

Table 6 compares some of the features of the four systems evaluated. All four passed the temperature and humidity tests, and we expect that all four will operate successfully for long periods of typical DOE storage radiation exposure. The electronics in the FSI and Inovonics systems are probably more susceptible to radiation-damage failure than the electronics in the other systems. In our tests, the two memory chips, Electronically Erasable Programmable Memory and the AC-11 microprocessor with on-board memory, were erased by the gamma radiation. 
Table 6 - Active Seal Technologies Feature Comparison Matrix

\begin{tabular}{|r|c|c|c|c|}
\cline { 2 - 4 } \multicolumn{1}{c|}{} & $\begin{array}{c}\text { Interactive } \\
\text { Technologies, } \\
\text { Inc. }\end{array}$ & $\begin{array}{c}\text { Fiber } \\
\text { SenSys, } \\
\text { Inc. }\end{array}$ & $\begin{array}{c}\text { Inovonics } \\
\text { Corporation }\end{array}$ & $\begin{array}{c}\text { Valve } \\
\text { Security } \\
\text { Systems }\end{array}$ \\
\hline Light Source & LED & Laser & LED & LED \\
\hline Fiber Optic Motion, Vibration \& Pressure Sensing Cable & & $\mathrm{X}$ & & \\
\hline Fiber Optic Optical Continuity & $\mathrm{X}$ & & $\mathrm{X}$ & $\mathrm{X}$ \\
\hline Random Pulsing Light Source & $\mathrm{X}$ & $\mathrm{X}$ & $\mathrm{X}$ & $\mathrm{X}$ \\
\hline Maximum Fiber Optic Cable Length Per Loop & $150 \mathrm{ft}$ & $656 \mathrm{ft}$ & $100 \mathrm{ft}$ & $500 \mathrm{ft}$. \\
\hline Uses Glass Fiber Optic Cable & & $\mathrm{X}$ & & \\
\hline Uses Plastic Fiber Optic Cable & $\mathrm{X}$ & & $\mathrm{X}$ & $\mathrm{X}$ \\
\hline Signal Processing for Natural Phenomenon Disturbances & & $\mathrm{X}$ & & \\
\hline Circuit Card Contact Tamper Switch/ Alarm & $\mathrm{X}$ & & $\mathrm{X}$ & \\
\hline Number of Containers Protected to Reach \$100 Cost Factor & 41 & 187 & 86 & 39 \\
\hline Motion Sensor Addd-On Capabilities & $\mathrm{X}$ & built in & $\mathrm{X}$ & \\
\hline Hand-Held Calibrator w/ Security Key & & $\mathrm{X}$ & & \\
\hline Alpha/Numeric Keys with Alpha/Numeric Display Unit & $\mathrm{X}$ & & & \\
\hline
\end{tabular}

Table 7 shows the ranking of the seals tested where " 1 " represents the best rating in that particular category. All of the seals could be defeated by the vulnerability analysts if they were allowed an unconstrained environment, but none could be readily defeated in the two-person environment.

\section{Table 7- Active Seal Technologies Comparison}

\begin{tabular}{|l|c|c|c|c|}
\hline Manufacturer & $\begin{array}{c}\text { Cost } \\
\text { Factor }\end{array}$ & $\begin{array}{c}\text { Climatic } \\
\text { Test }\end{array}$ & $\begin{array}{c}\text { Radiation } \\
\text { Test }\end{array}$ & $\begin{array}{c}\text { Tamper } \\
\text { Resistance }\end{array}$ \\
\hline FSI & 4 & 1 & 2 & 1 \\
\hline ITI & 2 & 1 & 1 & 2 \\
\hline Inovonics & 3 & 1 & 2 & 3 \\
\hline VSS & 1 & 1 & 1 & 4 \\
\hline
\end{tabular}

It seems that the primary trade-offs to be made are between the cost and level of protection desired. The systems that provide higher tamper resistance are more sophisticated and, therefore, more expensive. Other factors may also enter into selection decisions such as 1) VSS and ITI support other types of sensors, and 2) Inovonics presently uses only short fiber loops but FSI uses very long loops.

In conclusion, we believe that any of the four systems can meet some current DOE needs and recommend that all be considered for use at DOE facilities. Which systems to use will be strongly driven by the particular storage configuration. Another major consideration is the system's ability to integrate with other elements to provide balanced, complete protection of SNM in a vault situation. 


\section{DISTRIBUTION:}

1 Office of Security Affairs, NN-50

General George L. McFadden, Director

U.S. Department of Energy

Washington, DC 20585

1 Edward J. McCallum, Director

Office of Safeguards and Security, NN-51

U.S. Department of Energy

Washington, DC 20585

1 David A. Jones, Director

Policy, Standards, and Analysis Division, NN-512

U.S. Department of Energy

Washington, DC 20585

$2 \quad$ U.S. Department of Energy

Attn: William J. Desmond, Program Manager(1)

Attn: Darryl Toms(1)

Physical Security Branch, NN-512.1

Washington, DC 20585

1 Lynne Gebrowsky, Program Manager

Personnel Security Policy, Procedures, Analysis

Branch, NN-512.2

U.S. Department of Energy

Washington, DC 20585

1 Larry D. Wilcher, Program Manager

Technical and Operations Security

Branch, NN-512.3

U.S. Department of Energy

Washington, DC 20585

2 U.S.Department of Energy

Attn: David W. Crawford, Program Manager

Attn: James Crabtree

Materials Control and Accounting

Branch, NN-512.4

U.S. Department of Energy

Washington, DC 20585

1 G. Bowser, Program Manager

Assessment and Integration Branch, NN-513.1

U.S. Department of Energy

Washington, DC 20585

1 Donald J. Solich, Program Manager

Weapons Safeguards and Security Operations

Branch, NN-513.2

U.S. Department of Energy

Washington, DC 20585
G. Griffin, Program Manager, Actg

Production/Energy Safeguards/Security

Operations Branch, NN-513.3

U.S. Department of Energy

Washington, DC 20585

U.S. Department of Energy

Attn: G. Dan Smith, Program Manager(1)

Attn: Carl A. Pocratsky(1)

Planning and Technology Development Branch, NN-513.4

Washington, DC 20585

1 Marshall O. Combs, Director

Headquarters Operations Division, NN-514

U.S. Department of Energy

Washington, DC 20585

1 Charles C. Coker, Program Manager

Physical Protection Branch, NN-514.1

U.S. Department of Energy

Washington, DC 20585

Floyd McCloud, Program Manager

Technical/Information Security Branch,

NN-514.2

U.S. Department of Energy

Washington, DC 20585

$1 \quad$ Kenneth Sanders, Director Intemational Safeguards Division, NN-44

U.S. Department of Energy

Washington, DC 20585

Bryan Siebert, Jr., Director

Office of Declassification, NN-52

U.S. Department of Energy

Washington, DC 20585

William Hensley, Director

Office of Engineering, Operations, Security, and Transition Support, DP-31

U.S. Department of Energy

Washington, DC 20585

1 R. Crow, Director

Office of RD\&T Facilities, DP-65

U.S. Department of Energy

Washington, DC 20585

Glen S. Podonsky, Deputy Assistant Secretary

Office of Oversight, EH-2

U.S. Department of Energy

Washington, DC 20585 
$1 \quad$ Vincent J. Moskaitis

Office of Plans, Technology, and

Certification, EH-4.3

U.S. Department of Energy

Washington, DC 20585

1 HEADQUARTERS, USAFE

Attn: Director, Plans and Programs

Unit 3050, Box 135

APO-AE 09094-5000

$1 \quad$ U.S. Army Military Police School

ATZN-MP-TS (Capt. Sanders)

Fort McClellan, AL 36205-5030

1 Commander

U.S. Army Engineering Division

Attn: HNDED-ME, Electronic Technology

PO Box 1600

Huntsville, AL 35806

1 Naval Civil Engineering Laboratory

Attn: G. Cook, L-56

Port Hueneme, CA 93043

1 General Atomics

Attn: C. L. Wishsam, Manager

Nuclear Material Accountability

PO Box 85608

San Diego, CA 92138-5608

1 Rocketdyne

Attn: P. Horton, Manager

Nuclear Operations Dept. 642, MS T034

PO Box 7922

Canoga Park, CA 91309-7922

Donald Wentz, Director

Safeguards and Security

Lawrence Livermore National Laboratory

PO Box 808

Livermore, CA 94550

1 Interactive Technologies, Inc.

Attn: Bob Heimbecker

2266 North Second St.

North St. Paul, MN 55109

1 Sandia National Labs - Livermore

Attn: J. Goltz

PO Box 969

Livermore, CA 94550-0096
1 K. J. Heidemann, Director

U.S. Department of Energy/RF

Safeguards and Security Division

PO Box 928

Golden, CO 80402-0928

6

SAIC

Attn: F. D. James(1)

Attn: R. E. Kellam(1)

Attn: M. Castro(1)

Attn: G. Agurio(1)

Attn: G. Nelson(1)

Attn: D. J. Frank(1)

PO Box 928

Golden, CO 80401

1

G. P. Morgan, Director

U.S. Department of Energy

Western Area Power Administration

Division of Energy Services and Security Affairs, A0410

1667 Cole Boulevard, Bldg 18

Golden, CO 80401-0456

1 James Hartman, Assistant Manager

Site Support and Security

U.S. Department of Energy/RF

PO Box 958, Bldg 115

Golden, CO 80402-0464

$1 \quad$ Chief of Security Police

Air Force Space Command

Peterson Air Force Base

Colorado 80914-5001

1 James W. Atherton, SA

Federal Bureau of Investigation

Washington Field Office

10th Street and Pennsylvania Ave. NW

Washington, DC 20537

1 Raymond Brady, Director

U.S. Nuclear Regulatory Commission

Division of Security

Washington, DC 20555

Fred Branch, Chief - Physical Security Branch U.S. Department of State

DS/PSD Room 804, SA6

Washington, DC 20520 
Robert Burnett, Director

U.S. Nuclear Regulatory Commission

Div. of Fuel Cycle, Safety, \& Safeguards,NMSS

Mail Stop 8-A-33 TWFN

Washington, DC 20555

1 Director, Systems Protection

OASD (C3I), DASD (I\&S), CI\&SP, 3C260

6000 Defense Pentagon

Washington, DC 20301-6000

1 Central Intelligence Agency

Director, Office of Security

202 Jefferson

Washington, DC 20505

1 Priscilla A. Dwyer

U.S. Nuclear Regulatory Commission

Div. of Fuel Cycle, Safety \& Safeguards, NMSS

Washington, DC 20555

1 Tom Fey

U.S. Department of State

DS/PI/PRD, State Annex 1

2201 C Street NW

Washington, DC 20520

1 John C. Hagan

National Aeronautics and Space Administration

Security Office (NIS)

Washington, DC 20546

1 U.S. Department of Justice

Federal Bureau of Prisons

Attn: Jim Mahan, Room 300

320 First Street NW

Washington, DC 20534

1 J. Partlow, Director

U.S. Nuclear Regulatory Commission

Division of Inspection Programs

Washington, DC 20555

1 HEADQUARTERS, USAF/SPX

Attn: LtCol Mike Pasquin

1340 Air Force

The Pentagon

Washington, DC 20330-1340

1 HEADQUARTERS, USAF/SPO

Attn: Maj John M. Reis

1340 Air Force

The Pentagon

Washington, DC 20330-1340
C. C. Slagle, Manager

Technical Division

U.S. Bureau of Engraving \& Printing,Rm 303M

14th and C Street NW

Washington, DC 20228

1 Richard J. Solan, Chief

U.S. Secret Service

Security Division/Planning and Development 1800 G Street NW, Room 941

Washington, DC 20223

1 Department of the Navy (CNO N-O9N)

Attn: Leo L. Targosz, Jr.

Washington, DC 20388-5024

1 Michael Toscano, Chairman

DoD Physical Security Equipment

Advisory Group, OUSD (A\&T)

The Pentagon, Room 3B1060

Washington, DC 20301

1 Stanley W. Zack, Jr.

Federal Bureau of Investigation

Washington Field Office

10th Street and Pennsylvania Avenue NW

Washington, DC 20537

1 HEADQUARTERS, PACAF/SPPA

Attn: Director, Plans and Programs

Hickam Air Force Base, Hawaii 96853

1 B. G. Essary, General Manager

Protection Technologies of Idaho

785 DOE Place

Idaho Falls, ID 83402

1 Richard L. Green, Director

U.S. Department of Energy/ID

Safeguards and Security Division

785 DOE Place

Idaho Falls, ID 83402

3

Lockheed Idaho Technologies Company

Attn: John J. Noon, Director(1)

Safeguards and Security

Attn: E. L. Goldman, Manager(1)

Safeguards and Security Technical Operations

Attn: Roger O. Cook, Supervisor(1)

PO Box 1624

Security Equipment Systems

Idaho Falls, ID 83415 
$1 \quad$ Bruce Meppen, Manager

Safeguards and Security

U.S. Department of Energy

Argonne National Laboratory, Idaho Site

PO Box 2528

Idaho Falls, ID 83403-2528

1 Charleton Bingham, Director

U.S. Department of Energy/CH

New Brunswick Laboratory

Safeguards and Security Division

Argonne, IL 60439

1 Thomas Gradle, Director

U.S. Department of Energy/CH

Safeguards and Security Division

Argonne, IL 60439

2 Argonne National Laboratory

Attn: K. W. Poupa (1)

Attn: D. G. Erick (1)

9700 South Cass Avenue

Argonne, IL 60439

$1 \quad$ Rudy Dorner

Fermi National Accelerator Laboratory - MS 102

Batavia, IL 60150

1 J. Dollinger, Security Department

Boeing Petroleum Services

850 South Clearview

New Orleans, LA 70123

1 Donald J. Ornick, Director, Security Division U.S. Department of Energy/OR 900 Commerce Road East

New Orleans, LA 70123

1 Wackenhut Services, Inc.

800 West Commerce Road, Suite 100

New Orleans, LA 70123

1 A. L. Lavery

Transportation Systems Center

Kendall Square

Cambridge, MA 02142

4 HEADQUARTERS, ESC

Attn: Doug Dalessio, AVJ (1)

Attn: Don Carr, AVJF (1)

Attn: $\quad$ Morry Outwater, AVJR (1)

Attn: Capt. Jamie Thurber, AVJG TASS (1)

20 Schilling Circle

Hanscom Air Force Base

Massachusetts 01731-2816
$1 \quad$ Michael Kraynick, Mail Stop 51

National Security Agency

Fort Meade, MD 20755

1 Tyden Seal Co.

Attn: Steven J. Trent

210 N. Industrial Park Road

Hastings, MI 49058

2 AlliedSignal, Inc.

Attn: $\quad$ S. J. Baker, Manager (1)

Attn: S. V. Zvacek, Supervisor (1)

Security and Emergency Management

Kansas City, MO 64141-6159

1 Commanding General

USAJFKSWCS / SOTIC

Fort Bragg, NC 28307-5000

1 Commanding General

1 st SOCOM

ODCOPS-Special Projects

Fort Bragg, NC 28307

1

Col. William F. Garrison

Department of the Army

1st Special Forces Operational, Det-Delta

Fort Bragg, NC 28307-5000

1 John Trout

U.S. Army Corps of Engineers, MROED-S

215 North 17 th Street

Omaha, NE 68102

1 E. J. Brooks Co.

Attn: R. I. Atlas

64 N. 13th Street

Newark, NJ 07107

2

U.S. Department of Energy

Safeguards and Security

Central Training Academy

Attn: Stan Laktasic

Attn: Walter Strohm

PO Box 18041

Albuquerque, NM 87185

U.S. Department of Energy, SNSD/AL

Attn: Ms. Linda L. Mueller, Acting Director Security and Nuclear Safeguards Directorate PO Box 5400

Albuquerque, NM 87185 
PO Box 5400

Albuquerque NM 87185

Director, Physical Security

$8201 \mathrm{H}$ Avenue SE

Kirtland Air Force Base

New Mexico 87117-5664

1 Director of Operations (SPO)

Air Force Agency Security Police

Kirtland Air Force Base

New Mexico 87117-5000

1 D. B. Smith, N-DO/SG

Los Alamos National Laboratory

Mail Stop: E550

PO Box 1663

Los Alamos, NM 87545

1 E. Wayne Adams, Director

Safeguards and Security Division

U.S. Department of Energy/NV

PO Box 98518

Las Vegas, NV 89193-8518

1 Raytheon Services, Inc.

Attn: Electronics Department

PO Box 93838

Las Vegas, NV 89193-3838

1 LLNL-NTO

Attn: P. Stathis, Material Management

PO Box 45

Mercury, NV 89023

1 George G. Stefani, Jr., Director

Safeguards and Security Division

U.S. Department of Energy

Schenectady Naval Reactors Office

PO Box 1069

Schenectady, NY 12301

2 U.S. Department of Energy

Brookhaven Area Office

Attn: Joseph Indusi, Bldg 197C (1)

Attn: Kris Dahms, Bldg 703 (1)

53 Bell Avenue

Upton, NY 11973

Stoffel Seals Corp

Attn: J. P. Kelly

PO Box 825

Nyack, NY 10960

485th EIG/EICI

Griffiss Air Force Base

New York 13441-6348

1 Daniel Baker, Security Manager

EG\&G Mound

PO Box 3000

Building 99

Miamisburg, $\mathrm{OH} 45342$

J. M. Miller, Manager

Westinghouse Materials Company of Ohio

Safeguards and Security

PO Box 898704

Cincinnati, $\mathrm{OH} 45239$

1 Battelle Memorial Institute

Nuclear Services

Attn: H. Toy, Manager

Columbus, $\mathrm{OH} 43201$

Robert L. Windus, Security Manager

U.S. Department of Energy/BP

PO Box 3621

Portland, OR 97208

J. A. Bullian, Director

U.S. Department of Energy/PNR

Safeguards and Security Division

PO Box 109

West Mifflin, PA 15122

Advantage Technology, Inc.

Attn: P. Luxion

PO Box 10155

Lancaster, PA 17605-0155

A. H. Hopfinger, Manager

Laboratory Operational Safeguards, $62 \mathrm{M}$

Bettis Atomic Power Laboratory

Westinghouse Electric Corporation

Box 79

West Mifflin, PA 15122-0079 
Westinghouse Savannah River Company

Attn: J. W. Dorrycott, Division Manager (1)

Safeguards, Security, \& Emergency

Preparedness

Attn: $\quad$ R. E. Gmitter, Manager (1)

Safeguards and Security Programs

PO Box 616

Aiken, SC 29802

4

U.S. Department of Energy/SR

Office of Safeguards and Security

Attn: Larry Brown, Director (1)

Attn: Larry Ogletree, Director (1)

Safeguards Engineering and Projects Br.

Attn: Tom Williams, Branch Chief (1)

Safeguards and Classification

Attn: Steve Shelt (1)

Information and Protection Branch

PO Box A

Aiken, SC 29802

1 W. L. Clements, Division Manager

Martin Marietta Energy Systems

Y-12 Safeguards and Security

Bldg 9706-1, MS 8212

Oak Ridge, TN 37831-8213

1 Oak Ridge National Laboratory

Attn: M. H. Ehinger

PO Box 2008

Oak Ridge, TN 37831

3 Martin Marietta Energy Systems

Y-12 Safeguards and Security

Attn: M. Fuller(1)

Attn: Cathy Key(1)

Attn: Chris Pickett (1)

Oak Ridge, TN 37831-8213

1 William G. Phelps, Director

U.S. Department of Energy/OR

Safeguards and Security Division

PO Box 2001

Oak Ridge, TN 37831-857

1 James J. Hallihan, Director,

Safeguards and Security, Pantex Plant

Mason and Hanger-Silas Mason Company, Inc.

PO Box 30020

Amarillo, TX 79177-001

1 Chief of Security Police

Air Force Intelligence Command

Kelly Air Force Base, Texas 78243-5000
1 Belvoir Research, Development, \& Engr. Center Product Manager, Physical Security Equipment Attn: AMCPM-PSE

Fort Belvoir, VA 22060-5606

2

Belvoir Research, Development, and

Engineering Center

Attn: STRBE-JI (A. Zushin)(1)

Attn: STRBE-ZM (J. M. Hale)(1)

Fort Belvoir, VA 22060-5606

$1 \quad$ Jerry Edwards

U.S. Army PSEMO

Attn: AMSAT-W-TP -BRDEC

Fort Belvoir, VA 22060-5606

$1 \quad$ William J. Witter

Defense Nuclear Agency (NOSA)

6801 Telegraph Road

Alexandria, VA 22310-3398

$1 \quad$ Craig Walton, Manager

Westinghouse Hanford Company

Safeguards and Security Division

PO Box 1970, Mail Stop L4-01

Richland, WA 99352

1 J. L. Spracklen, Director

U.S. Department of Energy/RL

Safeguards and Security Division

PO Box 550, Mail Stop A6-35

Richland, WA 99352

$4 \quad$ Pacific Northwest Lab

Attn: O. Amacker, Jr.(1)

Attn: S. Gordy(1)

Attn: J. Griggs(1)

Attn: J. Abraham(1)

PO Box 999

Richland, WA 99352

$1 \quad$ VSS Fiber Optic Sensors

Attn: Rodney Conrad

11356 West 107 th Place

Denver, CO 80021

$1 \quad$ Valve Security Systems

Attn: Frederick W. Wiese

PO Box 1141

Ballwin, MO 63022-1141 
Fiber SenSys, Inc.

Attn: Sandra Reynolds

9640 SW Sunshine Ct, \#400

Beaverton, OR 97005

1 Inovonics Corporation

Attn: Steve Koonce

2100 Central Ave

Boulder, CO 80301 


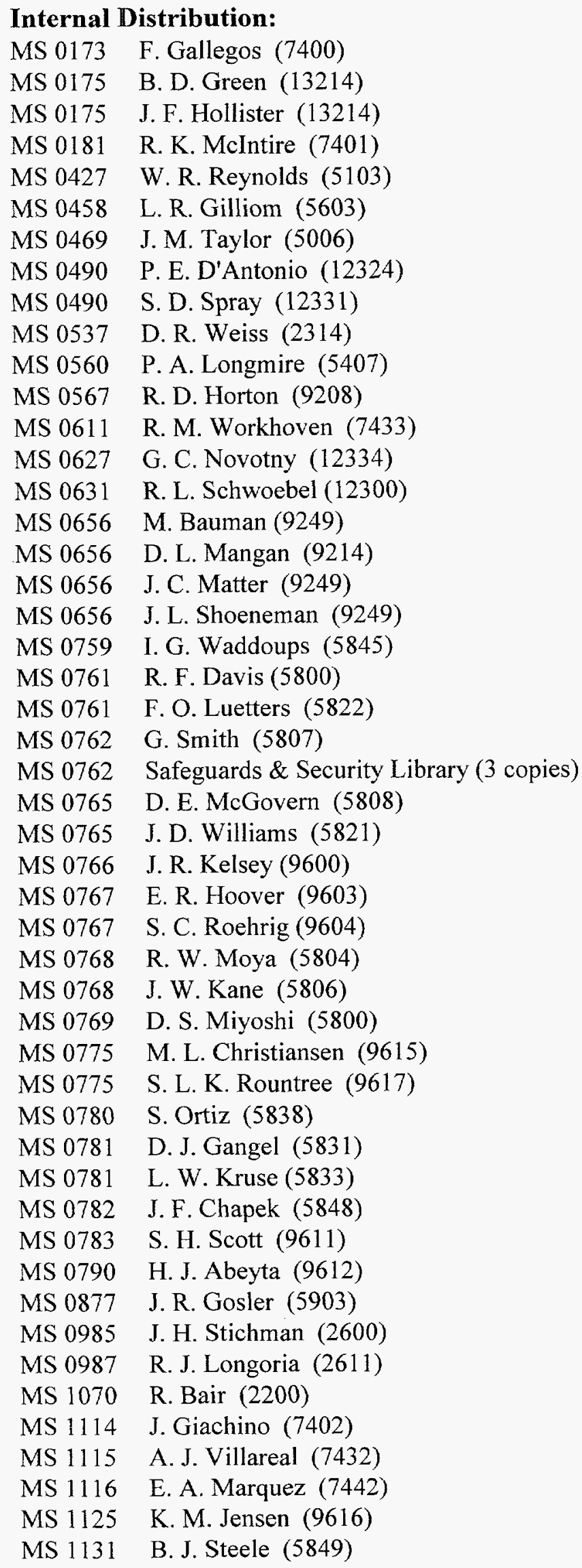

MS 9004 M. John (8100)

MS 9020 S. C. Gray (8632)

MS 9105 L. Hiles (8400)

MS 9018 Central Technical Files (8523-2)

MS 0899 Technical Library (13414)(5 cy)

MS 0619 Print Media (12615)

MS 0100 Document Processing (7613-2)

For DOE/OSTI (2 cy) 